
\title{
CIÊNCIA'NATURA
}

\section{EVOLUTION OF INTEGRATED SOLID WASTE MANAGEMENT SYS- TEMS IN BRAZILIAN CITIES UNDER THE NATIONAL SOLID WASTE POLICY}

\author{
Gabriel de Pinna Mendez e Claudio Fernando Mahler
}

Universidade Federal do Rio de Janeiro, Brasil

\begin{abstract}
This article analyzes the evolution of integrated solid waste management systems in small and medium cities of the state of Rio de Janeiro. For this purpose, we applied the Modified Solid Waste Management Condition Index (ICGRm), calculated by a spreadsheet with 40 environmental indicators. A field study was carried out to evaluate ten cities in the state of Rio de Janeiro, among twenty already investigated in a survey carried out in the years 2007-2008. The cities were classified as adequate or inadequate according to the ICGRm scores (range from zero to ten points). The comparative evaluation revealed that four cities presented positive evolution, but only slight, while six cities presented worse scores. This work contributes to public administration in general by presenting an analytic framework to indicate weaknesses existing in waste management systems. In the specific case of Brazil, it shows that public managers have not yet given proper priority to solid waste management, although six years have passed since the establishment of the National Solid Waste Policy through Law 12,305/2010. Ten of the cities evaluated reached the level of management considered adequate by the applied method, either in the evaluation in 2007-2008 or 2016, and some showed slight improvement.
\end{abstract}

Keywords: Integrated management systems. Solid waste management. Environmental assessment. Environmental indicators 


\section{Introduction}

Dantas et al. (2016) observed that the poor performance in municipal waste management is still a problem that affects Brazilian society as a whole. In most cities, public managers have not yet taken proper measures to treat this issue as one of the most relevant ones. Federal Law 12.305 of 2010 established the National Solid Waste Policy (PNRS), which took almost 20 years in Congress to approve, reflecting the great difficulties and bureaucratic barriers to be overcome. Unfortunately, the effectiveness of this law has not been observed yet. According to the PNRS - National Policy of Waste in Brazil, open dumps should have been closed by 2014, but according to Fernandes (2015), in a survey carried out in 2014 of the 5,570 Brazilian municipalities, only 844 had sanitary landfills for disposal, waste was sent to dumps in 1,775 cities and 2,951 did not even respond to the survey. Fernandes (2015) also reported that only $36.3 \%$ of the cities surveyed in 2014 had established the required basic municipal sanitation plan and about 37\% performed some type of selective collection. Godoy (2013) showed that at the end of August 2012, only 10\% of cities had developed the required local solid waste plans. A bill approved by the Senate (PLS $425 / 2014$ ), but still under debate in the Chamber of Deputies, would extend the deadline for cities to eradicate open dumps.

The PNRS established some instruments and guidelines that should be applied by cities regarding integrated solid waste management systems (ISWMS), such as targets for reuse and recycling and percentages of biodegradable organic matter, along with incentives for new treatment techniques, better final disposal and energy generation from the biogas produced from the degradation of waste. The overall aim is to provide universal coverage of waste collection and proper disposal, with financial self-sustainability.

According to Marshall and Farahbakhsh (2013), developing countries such as Brazil need to invest in the scientific, theoretical and practical growth aspects of solid waste management, allowing the creation of participatory, contextual and adaptive strategies that enable real progress of the country's infrastructure. Unfortunately, in Brazil the basic sanitation sector is still deficient, heterogeneous and presents regional contrasts, mainly concerning solid waste management, and constitutes a huge challenge for municipal managers.

The increase in population density and economic growth lead to an increase in the generation of municipal solid waste. It is the municipal government's responsibility, directly or indirectly, to collect, treat and/or appropriately allocate the municipal solid waste generated by the population. This task demands, besides efficiency in the allocation of resources, procedures of good public management such as environmental awareness and social and political responsibility, attributes that are scarce in most cases. Inefficient waste management has caused serious damage to the environment and society. According to Dantas et al. (2016), environmental management of urban solid waste needs better articulation between the levels of government: federal, state and municipal.

The aim of this study was to verify if evolution has occurred in integrated solid waste management systems, besides quantifying the effectiveness of these systems through the ICGRm, proposed and validated by Dantas et al. (2016). The ICGRm starts from the premise that the management of solid waste in a city cannot be evaluated only by the situation of the final disposal. Important aspects such as street sweeping, collection, environmental education and forms of storage by citizens should be considered. The environmental degradation of water bodies has increased as a result of management problems such as poorly collected or irregular discarded waste, badly swept public spaces, etc. In 2007 and 2008, 20 cities in the state of Rio de Janeiro were evaluated through the ICGRm and the results were presented in Dantas et al. (2016). The present study evaluated 10 of these 20 cities in order to obtain comparative results and quantify both positive and negative evolution according to the ICGRm score.

\section{Material and Methods}

The evaluation in this study used as a tool the ICGRm proposed by Dantas et al. (2016), which has as a unique characteristic the conception that the management of waste in cities should be evaluated as an integrated system. The situation of the treatment and final disposal units cannot demonstrate, in isolation, the conditions of waste management in cities. From an initial diagnosis, Environmental Condition Indicators (ICA) and Environmental Performance Indicators (IDA) were selected according to ISO 14.031, related to solid waste management, which allowed preparation of the ICGRm worksheet. To analyze the conditions of the integrated management system, an evaluation method was created that includes 40 indicators grouped as subitems related to three groups of indicators: system infrastructure, service planning, and execution. These indicators should reveal, within a range of values, the conditions of the integrated management system of municipal solid waste in the cities. The central idea is that these indicators can demonstrate the areas with the greatest nonconformities in system management (DANTAS et al., 2016).

In 2007 and 2008, for validation of the proposed method, 20 cities were visited, 14 of them located in the mountainous region of the state of Rio de Janeiro and the other six adjacent to this region. In 2016, 10 of these 20 cities were evaluated again through a data survey that was conducted by means of an interview with municipal managers. The data collection included information on the types of treatment and final disposal of solid waste, considering the alternatives adopted for management, 
such as landfills, energy recovery plants, sorting units, recycling, composting units, pruning, weeding and gardening, treatment of waste from health services and treatment of construction waste.

During the field visits, information on the solid waste management system in the selected cities was obtained, in a model similar to that of environmental audits. The information given by the municipal managers was not considered absolutely true. To confirm the data, a survey was carried out of official websites of entities of the federal, state and municipal governments, such as the Ministry of Cities, Brazilian Institute of Geography and Statistics (IBGE) and various environmental agencies. In addition, residents, merchants and public officials and outsourced staff were polled to confirm the information obtained.

The information required for assessment was verified in loco. Items such as visual aspects of the site for cleaning, sweeping, weeding, mowing and pruning, proper removal of waste, pre-collection of waste, and other indicators in the index were observed.

After carrying out the data collection, it was possible to analyze the situation of each city in relation to integrated solid waste management. Each city evaluated received an "adequate management" or "inadequate management" designation, according to the range of values of the ICGRm, enabling a critical analysis of the data collected. It is important to emphasize that the research carried out aimed to analyze the evolution in the integrated waste management systems of the cities evaluated from the first analysis in 2007-2008 and the second one in 2016, and in no way detracts from past administrations and especially current ones.

\subsection{The Integrated Solid Waste Management System}

The concept of integrated solid waste management is based on the interrelation of processes and aspects involved and also takes in consideration the most appropriate treatment and disposal alternatives for each type of waste, as applicable to each city. "Landfills still remain as a strategic alternative to the integrated MSW management system. However, the tendency in developed countries is to reduce the volume of waste sent to landfills, as well as to forbid taking biodegradable waste to final disposal in landfills, which should also be a goal of Brazilian cities, through the implementation of alternative treatment techniques such as composting, fermentation, recycling and incineration with energy utilization" (DANTAS et al., 2016). The ISWMS concept begins with a careful preliminary diagnosis of municipal waste management, revealing the potentialities and weaknesses of the current system and opportunities for improvement. The diagnosis should also lead to estimates of future waste generation and costs for the implementation of new treatment units. The possibility of management associated with other cities (consortiums) needs to be developed as an alternative to gain scale and to find easier solutions of this problem. The formation of these consortiums should aim at the construction and operation of waste treatment and disposal centers, which can receive waste from several cities, as well as having sufficient volume for biogas generation and capture. The question of organic waste must be carefully considered by managers, because putrescible organic matter represents in Brazil 50-60\% of the gravimetric composition of the waste generated in cities. In this respect, the assignment of responsibility for certain waste types is a common practice in developed countries, especially for families residing in areas that contain gardens and yards, with enough room for single-family composting.

\subsection{Environmental Evaluation: Using Indicators}

In municipal solid waste management, the indicators make it possible to observe and monitor the situation of a city regarding aspects of the ISWMS. According to Dantas et al. (2016), in the process of preparing the evaluation worksheets, it is necessary to reduce and group the standardized indicators and determine the importance of each one, referencing them to a section of the PDCA cycle (Plan-Do-Correct-Act) with the objective of facilitating the critical analysis. The purpose of standardization is to express the indicators in comparable values, allocated by management sectors.

According to CETESB (2002), in Brazil, the state of São Paulo was a pioneer in evaluations in the area of solid waste by implementing a system to survey the status of final waste disposal in 1997. It also implemented an annual Inventory of Urban Solid Waste, which included a landfill evaluation method called the Urban Solid Waste Landfill Quality Index (IQR for short in Portuguese). Research carried out by the Study Group on Solid Waste Treatment (GETRES) of Coppe/UFRJ provided input to improve the methods of assessing waste disposal and integrated management systems.

During the 19 years of applying the IQR assessment method and its necessary updating, substantial improvements in the environmental conditions of the final municipal waste disposal sites of the state of São Paulo have been achieved, as can be seen in Figures 1 and 2.

\subsection{A New Method to Evaluate the ISWMS: Modified Solid Waste Management Condition Index (IC-}

\section{GRm)}

According to Dantas et al. (2016), taking into account that the composition of the integrated solid waste management system includes several tasks, alternatives and treatment and final disposal units, a method was developed that allows evaluating 


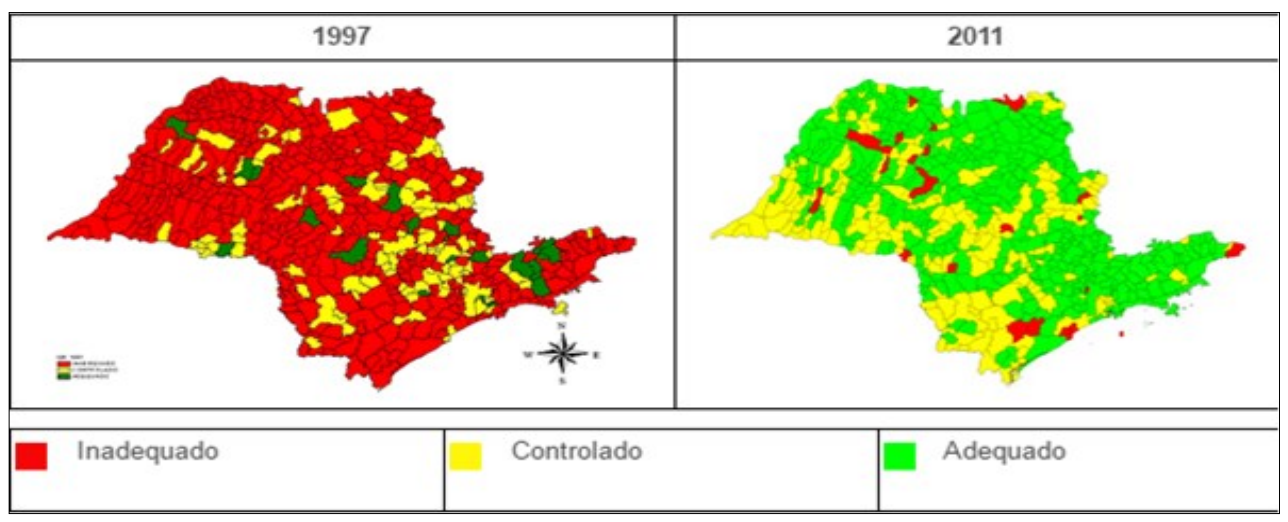

Figure 1 - Urban Solid Waste Landfill Quality Index (IQR) in the state of São Paulo - 1997-2011. Source: CETESB (2016)

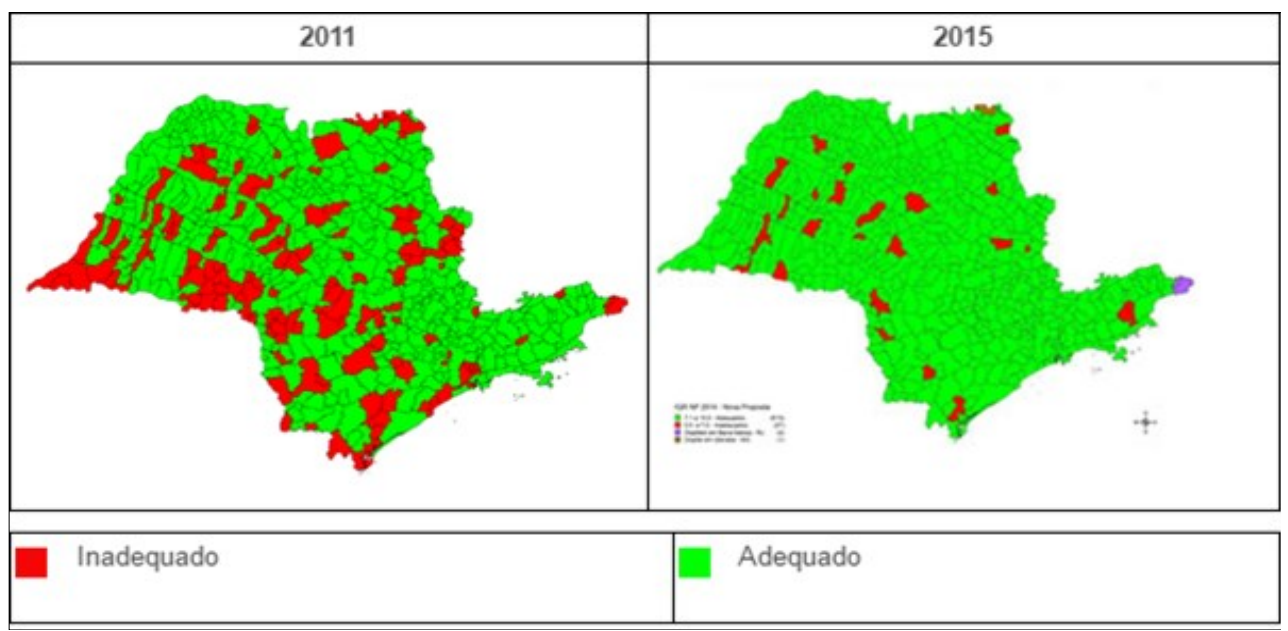

Figure 2 - IQR - Urban Solid Waste Landfill Quality Index (IQR) in the state of São Paulo - after 2011. Source: CETESB (2016)

the entire system, which is reduced in the end to an index capable of expressing the condition of waste management in cities. The method involves a spreadsheet with 40 indicators divided into three items, called the Modified Solid Waste Management Condition Index (ICGRm). The use of a wide variety of indicators in the evaluation of urban cleaning and waste management services is undoubtedly an acceptable methodological option, since it enriches the analysis. The ICGRm was used in the evaluation of 20 cities in the state of Rio de Janeiro and the results were reported by Dantas et al. (2016). The same methodology was applied in 10 of these 20 cities for this study. The indicators that make up the ICGRm worksheet are presented below:

\subsubsection{SYSTEM CHARACTERISTICS: maximum score 32}

This item comprises ten subitems or indicators that aim to characterize the integrated waste management system of a city. The system encompasses several types of waste: municipal solid waste, commercial waste, health, construction and special waste. At this stage the aim is to analyze issues related to collection, sweeping, weeding, fleet and equipment.

Coverage of regular households and commercial collection.

A score of 5 is given to cities that provide waste collection to more than $90 \%$ of the population; score 3 for between 70 and $90 \%$ of the population and score 0 for less than $70 \%$.

Selective collection.

This subitem is intended to give greater higher scores to cities that perform selective collection. If the selective collection is already implanted in every urban area of the city, the score is 5 ; if it is being implanted only in public schools or in specific neighborhoods or places, the score is 3 and if it is not being performed, the score is 0 . 
Collection of healthcare solid waste.

The cities that control or carry out the collection of healthcare solid waste (HSW) receive score 5 and those that do not control it receive 0 .

Collection of construction waste.

In this item, cities that collect construction waste receive a score of 3 and those that do not, are assigned a score of 0.

Collection of electrical and electronic equipment, batteries, batteries and lamps.

This subitem assigns a score of 1 for cities that have delivery points or collectors for disposal of these residues and 0 for those that do not.

Tire collection.

As above, cities that collect old tires receive a score of 1 and those that do not get 0 .

Visual aspect of the street sweeping

The cities are scored according to the visual aspect of street sweeping as follows: score 4 for good appearance, score 2 for regular and 0 for bad.

Visual aspect of the sites regarding weeding, mowing and pruning

The cities are scored according to the visual aspect of weeding, mowing and pruning of the sites as follows: score 4 for good appearance, score 2 for regular and 0 for bad.

Fleet of vehicles and equipment

This item assigns a score of 1 to cities where trucks, tractors, handcarts, sweepers, mowers, and other devices are considered adequate, and 0 otherwise.

Existence of trash bins in public places

When the number of collection bins is good, score 2 , when regular score 1 and when there are no collectors, the score is 0 .

\subsubsection{SYSTEM PLANNING: maximum score 38}

This item comprises 12 subitems that aim to evaluate how the planning of the integrated waste management system of a city is being carried out. The basis of all planning should be the waste management plan.

Record keeping of requests and complaints.

This item is fundamental for the introduction of improvements and planning of corrective actions in the system. If the city has this sector, the score is 2 , if it does not have this service, the score is 0 .

Inspection team.

If the city has auditors to control the services, the score is 3 , if it does not have them, the score is 0 .

Integrated waste management plan.

A score of 5 is assigned to cities that have a management plan and score 0 for those without one.

Regular collection planning.

The score for cities that carry out collection planning is 4 and for those that do not it is 0 .

Civil construction waste management planning.

For cities that carry out planning, management and inspection, the score 3 and for those who do not it is 0 .

Healthcare waste management planning.

Cities that carry out the planning of these services receive score 3 , and those that do not obtain 0 .

Planning of street sweeping.

Larger cities that execute this type of planning and the smaller ones that keep records of the sweeping realized daily receive score 3 and those that do not realize any type of planning or record keeping receive 0 .

Weeding, mowing and pruning planning.

For cities that perform planning of weeding, mowing and pruning, the score is 2 , and 0 for those that do not.

Environmental education and awareness programs.

Cities with fully deployed and executed programs (directed at the entire population) receive score of 5, with those having only partially deployed and executed programs receiving 3 and those without any such program obtaining 0 .

Economic self-sustainability.

A score 3 is awarded to cities that have a self-sustaining ISWMS and the 0 for systems that cannot achieve this condition.

Scavenger inclusion programs.

Cities that carry out programs for social inclusion of scavengers, the score is 3 and for those that do not, 0 .

Support for participatory management and management through inter-municipal consortiums.

If the city is taking action in this direction and is contacting other partner cities to solve regional problems, the score is 2 , and 0 otherwise. 


\subsubsection{OPERATING CONDITIONS: maximum score: 60}

This item comprises 18 subitems or indicators that aim to evaluate the operational conditions of the integrated municipal waste management system of a city. The execution of the services must be in accordance with the planning carried out.

Removal of public waste.

If this activity is well performed and the overall public garbage removal aspect is adequate, the city receives a score of 3 , while if this is performed improperly, the score is 0 .

Operation of regular household and commercial collection.

If the collection is being properly operated, the score is 5 . If the evaluation considers the collection performed partially adequate due to small failures in operationalization, then the score is 3 , and if it is being improperly performed the score is 0 .

Operation of selective collection.

A system that contains a type of door-to-door or voluntary delivery service (VDS) that works properly receives a score of 5. If some items were accomplished but other items not, the operation is partially adequate and the score is 3 . If the city does not perform selective collection or is performing it inadequately, since most of the items are not being attended, the score is 0 .

Financial control of the system.

Cities that perform financial record keeping have a score of 3 and those that do not perform any type of control have score 0 .

Performance control.

The cities that keep records of the performance of the ISWMS have score of 3 and those that do not have score 0 .

Critical assessment of nonconformities and introduction of goals and targets.

Cities that include critical evaluations have score of 2 and those that do not have score of 0 .

Final destination of HSW.

If the city performs selective of waste from organized and controlled health services, according to CONAMA (National Environmental Council) Resolution 358 and ANVISA (National Sanitary Surveillance Agency) Resolution 306, the score is 2 ; otherwise, the score is 0 .

Recycling unit operation.

For cities that perform or have a waste sorting and recycling unit with efficient separation through equipment (treadmills, presses) in good condition and operating properly, the score is 3 . Those that have recycling units that operate improperly or that do not have recycling units receive 0 score.

Reuse of organic waste.

If the assessment of composting plants indicates adequate condition, the score is 4 . If the conditions are controlled, the score is 2 and if the plant is inoperative or operating under inadequate conditions, the score is 0 . Also, if the city has a unit for energy use of organic waste, the score is 4 ; otherwise the score is 0 .

Final destination of municipal solid waste.

If the integrated management system has final disposal of municipal solid waste at a sanitary landfill or extracts energy from waste, the score is 5 . If disposal is in partially adequate landfill, the score is 3 and if MSW is discarded in a dump or otherwise in any other inadequate manner, the score is 0 .

Final destination of construction waste.

In general, the correct destination should be reuse or recycling in the form of aggregates (score 4). When the RCC generated in the city is sent to landfills, the score is 2 . Other forms of improper disposal have score 0 .

Cleaning of drains and gutters.

If the system provides for cleaning services for gutters, drains and public sewers and does them properly, the score is 2 ; otherwise it is 0 .

Removal of dead animals and abandoned vehicles.

If the system includes the these tasks, the score 2 ; if not 0 .

Special cleaning.

If the system includes the cleaning of empty lots, beaches, favelas (slums), areas of difficult access and other types of special cleaning, the score is 2 ; if not 0 .

Control of use and maintenance of vehicle fleet

If the city adequately controls the use and maintenance of the fleet, the score is 4 , or outsources these services to a qualified firm that must meet quality targets, the score is 4 . If no records are kept of fleet use and maintenance, the score is 0 .

Control of work accidents.

If the system includes work accident record keeping, the score is 3 ; if not, 0 .

Use of personal protective equipment by teams.

ISWMS tasks are mostly unhealthy. In order to obtain a score of 4, there must be control of use of PPE throughout the system. If the system does not control the use of PPE, it receives a score of 0 .

Control of team absenteeism.

If the system includes the absenteeism record keeping, the score is 3 ; if not, 0 . 
Mendez e Mahler : Evolution of integrated solid waste management systems in brazilian cities under the national solid waste policy

\begin{tabular}{|c|c|c|c|c|c|c|c|c|c|}
\hline \multicolumn{10}{|c|}{ INDICE DE CONDIÇAOO DA GESTẢO DE RESÍDUOS MODIFICADO - ICGRm } \\
\hline \multicolumn{5}{|c|}{ Municipio: } & \multicolumn{5}{|c|}{ Bacia Hidrograflca: } \\
\hline \multicolumn{5}{|c|}{ Örgảo ge sor. } & \multicolumn{5}{|c|}{ Consoricio: } \\
\hline \multicolumn{5}{|c|}{ Tipo de contrato de gestib: } & \multicolumn{5}{|c|}{ Data vistoria: } \\
\hline \multicolumn{2}{|c|}{ Responsável: } & Contatio: & & & \multicolumn{5}{|c|}{ Responsável pela vistoria: } \\
\hline Item & Sub-item & Avaliaçào & Peso & Pontos & Item & Sub-tem & Avaliaçào & Peso & Pontos \\
\hline \multirow{3}{*}{\multicolumn{2}{|c|}{$\begin{array}{l}\text { cobertura da } \\
\text { coleta regular } \\
\text { domicliar e comercial }\end{array}$}} & C $\geq 90 \%$ & 5 & & & \multirow{2}{*}{$\begin{array}{l}\text { nemo çáo do } \\
\text { bxo públice }\end{array}$} & adequasa & 4 & \\
\hline & & $70 \% \leq \mathrm{C}<90 \%$ & 3 & & & & in adequada & 0 & \\
\hline & & $c<70 \%$ & 0 & & & \multirow{2}{*}{ operacion alizacho da coleta } & adequasa & 5 & \\
\hline \multirow{9}{*}{$\begin{array}{l}\mathrm{C} \\
\mathrm{A} \\
\mathrm{R} \\
\mathrm{A} \\
\mathrm{C} \\
\mathrm{T} \\
\mathrm{E} \\
\mathrm{R} \\
\mathrm{i} \\
\mathrm{S}\end{array}$} & coleta seletvo & implantass & 5 & & & & parcam adeq & 3 & \\
\hline & de resiovos & parciamimplan. & 3 & & & domoliar e comencial & inasequasa & 0 & \\
\hline & reodaves & \begin{tabular}{|l|l|} 
nào realiza \\
\end{tabular} & 0 & & & oper acion alizaçăo & adequada & 5 & \\
\hline & coleta de residuos do & realiza/controla & 2 & & & da coleta & pardam adeq & 3 & \\
\hline & servico de saúde & กลี๋ & 0 & & & zeletive & näo real/nadeq. & 0 & \\
\hline & coleta de residuos da & realiza & 3 & & & controle & realza & 2 & \\
\hline & con stuçąo ovil & กล่० & 0 & & & Inanceiro do setema & näo realiza & 0 & \\
\hline & coleta de equip. eletrón, & gim & 1 & & & controle de & realza & 3 & \\
\hline & baterias, pilhas (n serv.) & não & 0 & & c & desempenho & näo realiza & 0 & \\
\hline $\mathrm{T}$ & coleta de & simi semrelev. & 1 & & 0 & avaliaçào critca - introduçào, & realza & 2 & \\
\hline$\cdot$ & pneus & nà่อ & 0 & & $\mathrm{~N}$ & de objetvose metas & nào realiza & 0 & \\
\hline D & aspecto visual & bom & 4 & & $\begin{array}{l}0 \\
1\end{array}$ & de sthação final & adequada & 3 & \\
\hline 0 & dos bgradounos & regular & 2 & & c & de RSS & in adequada & 0 & \\
\hline & quanto à varrição & nim & 0 & & ó & oper açäo de & adequada & 3 & \\
\hline s & aspecto visual & bom & 4 & & E & unid ade de reoclagem & in adeq. /inexist. & 0 & \\
\hline $\begin{array}{l}1 \\
5\end{array}$ & dos bgradouros quanto & regular & 2 & & s & reaproveiamento & adequado & 4 & \\
\hline $\begin{array}{l}S \\
T\end{array}$ & a capina, roçada e poda & nim & 0 & & & dos residuos & parcal & 2 & \\
\hline E & fota de veioulose & adeq. e sufc. & 4 & & $\begin{array}{l}0 \\
p\end{array}$ & orgánicos & inoper/inexist. & 0 & \\
\hline M & equipamentos & insut ou inadea & 0 & & E & de straçăo final & ater sanity a ene & 5 & \\
\hline A & existincia de & \begin{tabular}{|l|} 
sufcient \\
\end{tabular} & 3 & & $R$ & dos residuos solidos & ater parc adeq. & 3 & \\
\hline & papeleras e colvetores & regular & 2 & & A & urbanos do munichio & boblo/in adeq. & 0 & \\
\hline & hos bcais públicos & inexistente & 0 & & c & de sthaçio final & reutiz/recidagem & 4 & \\
\hline & sub-total 1 & máximo & 32 & & $\begin{array}{l}1 \\
0\end{array}$ & dos residuos da & aterro & 2 & \\
\hline item & Sub-item & Avalaçào & Peso & Pontos & $\mathrm{N}$ & Construgão ôvil & destn in adeq. & 0 & \\
\hline & controle de soliciaģes & $\sin$ & 2 & & A & realizaçào de Impe za de & $\operatorname{sim}$ & 2 & \\
\hline & e reclamapies & nào & 0 & & 1 & de ralose sarjetas & nâ० & 0 & \\
\hline & existencia de equipe & $\sin$ & 3 & & $\mathbf{s}$ & remoçào de animeis mothos & simr atvés solict. & 2 & \\
\hline p & de fscalizaçào & กล̃o & 0 & & & e veioubs abandonados & nào realize & 0 & \\
\hline L & existincia de Plano & $\operatorname{sim}$ & 5 & & & Impezas especias (verren os & $\operatorname{sim}$ & 2 & \\
\hline A & de Gestso & nå0 & 0 & & & vazios, praias, favelas, etc) & nào realiza & 0 & \\
\hline N & planejament do & $\sin$ & 4 & & & controle de uflizaçàoe & realizal berotiz. & 4 & \\
\hline E & coleta regular & $\ln 80$ & 0 & & & manutençbio da frota & In bo realiza & 0 & \\
\hline $\begin{array}{l}J \\
A\end{array}$ & plano inlegrado & $\operatorname{sim}$ & 3 & & & controle de acidentes & $\operatorname{sim}$ & 3 & \\
\hline$M$ & de gesto de RCC & กลีం & 0 & & & do trabaho & $\ln 80$ & 0 & \\
\hline$E$ & planejiament da & sim & 3 & & & controle de uflizaça & $\operatorname{sim}$ & 4 & \\
\hline $\mathrm{N}$ & geselbo de RSS & năo & 0 & & & EPI's (bots, Lve, másc, etc) & $\ln 30$ & 0 & \\
\hline $\mathbf{T}$ & planejament da & siml diánia & 3 & & & controle de absenteismo & $\operatorname{sim}$ & 3 & \\
\hline 0 & varricbo de logradounos & กลีo & 0 & & & nas equipes & nâo & 0 & \\
\hline D & existincla de plano de & $\operatorname{sim}$ & 2 & & & sub-total 3 & máximo & 60 & \\
\hline 0 & capina, roçada e poda & nào & 0 & & & & & & \\
\hline & programas de educaçäo & sim & 5 & & Some & dos pontos (Sub-total 1+2 & $+2+3)$ & 130 & \\
\hline s & anbental e & pancid & 3 & & & & & & \\
\hline $\begin{array}{l}1 \\
5\end{array}$ & conscientraç3o & não realiza & 0 & & $\overline{\text { ICGR }}$ & $R m=$ Soma dos pontos / 13 & & ICGR $=$ & \\
\hline$T$ & auto susten billdade & $\operatorname{sim}$ & 3 & & & & & & \\
\hline E & econômico inanceira & กล̃o & 0 & & & ICGRm & Avalia & ação & \\
\hline M & programes de indusbo & sin' aus catad. & 3 & & & 0 a 7,9 & Gestio in: & adequad: & \\
\hline A & de catadores no sisteme & กล๋̃ & 0 & & & 8,0 a 10,0 & Gestio ac & Sequada & \\
\hline & apoio à ge atbo parto- & $\operatorname{sim}$ & 2 & & & Avaliação: & & & \\
\hline & patve e consórcios & não & 0 & & & & & & \\
\hline & sub-total 2 & máximo & 38 & & & & & & \\
\hline
\end{tabular}

Figure 3 - ICGRm evaluation worksheet (DANTAS et al., 2016) 
The worksheet of Figure 3, below, was used for ICGRm evaluation in each city.

After evaluating the indicators through the service levels (scores), the points are summed by obtaining the subtotals of each item. The total is the sum of subtotal $1+$ subtotal $2+$ subtotal 3 and this number is divided by 13 . Thus, we arrive at the final score, which varies from 0 to 10 , to allow evaluating the solid waste management in the city according to two Ranges: 0 to $7.9 \rightarrow$ inadequate management; 8.0 to $10.0 \rightarrow$ adequate management.

\subsection{Activities: A Case Study in Rio de Janeiro}

According to Dantas et al. (2016), taking into account that the composition of the integrated solid waste management system includes several tasks, alternatives and treatment and final disposal units, a method was developed that allows evaluating the entire system, which is reduced in the end to an index capable of expressing the condition of waste management in cities. The method involves a spreadsheet with 40 indicators divided into three items, called the

The state of Rio de Janeiro is composed of 92 municipalities and the total population estimate, according to the Brazilian Institute of Geography and Statistics (IBGE) in 2016 was 15,989,929 inhabitants. The initial study was carried out in 20072008 in 20 cities in the state, 14 of them in the mountainous region and six adjacent to this region. The cities that make up the mountainous region are Bom Jardim, Cantagalo, Carmo, Cordeiro, Duas Barras, Macuco, Nova Friburgo, Petrópolis, Santa Maria Madalena, São Sebastião do Alto, São José do Vale do Rio Preto, Sumidouro, Teresópolis and Trajano de Morais. In addition to the mountainous region, the study included Cachoeiras de Macacu, Casimiro de Abreu, Conceição de Macabu, Carapebus, Quissamã and Silva Jardim. The total population estimated by the IBGE in 2006 for these 20 cities was 951,779 inhabitants and the estimated municipal solid waste generation was 753.8 metric tons per day.

In 2016, the cities of Cachoeiras de Macacu, Bom Jardim, Silva Jardim, Cantagalo, Nova Friburgo, Petrópolis, Teresópolis, São José do Vale do Rio Preto, Sumidouro and Casimiro de Abreu were studied in order to verify the evolution obtained in a period of eight years between the initial study and this one. The activities carried out consisted of visits and research in the cities selected about the treatment and final disposal units for the application of the index worksheet (ICGRm). The interviews with the municipal managers, responsible for waste management, were carried out most of the times with the environmental secretaries or their top aides, who accompanied the survey of the treatment and final disposal units. In addition, the information provided was double-checked when possible by consulting government databases, on-site verification and also from interviews with local residents, merchants and employees involved in waste management activities.

\section{Results}

It is important to note that the first survey was conducted in 2007-2008, approximately two years before the law establishing the National Solid Waste Policy (PNRS) was enacted. The second phase of the survey occurred in 2016, six years after this enactment, which initially created an expectation of considerable progress in the cities studied. In 2007-2008, all the cities presented inadequate management conditions. Among them, the city of Nova Friburgo obtained the best management score in this study, with 7.69 in the ICGRm, which was very close to the appropriate management condition $(>8.0)$. The greatest deficiencies were related to construction waste, the non-reuse of organic waste and the lack of inspection staff. The worst score for waste management was for Silva Jardim, which reached ICGRm $=3.00$. The city faced political and administrative problems that affected the performance of cleaning activities.

The surveyed cities that in 2007-2008 disposed of wastes in open dumps or allegedly (but not actually) controlled landfills were Cantagalo, Cachoeiras de Macacu, Carmo, São Sebastião do Alto, Silva Jardim, Teresópolis, Quissamã, Santa Maria Magdalena, São José do Vale do Rio Preto, Sumidouro and Trajano de Moraes. Only the cities of Nova Friburgo and Petrópolis sent waste to supposedly sanitary landfills. The results of the evaluations showed that the only recycling and composting unit operating under adequate conditions was in Sumidouro, which had different characteristics from the others, since it was a private facility (the municipal government outsourced the urban cleaning services to a company that designed, implemented, licensed and operated the plant, performing MSW treatment). A common issue for all recycling and composting units surveyed was that none of them performed quality control of the organic compound produced.

Table 1 below shows the results of ICGRm evaluations, according to each item, showing the nonconformities of management in each city in 2008. The italicized indications refer to scores lower than 8.0 and the ones in bold type are equal to or above 8.0 .

In 2016, none of the 10 cities evaluated presented adequate management, like in the first phase of the survey in $2007-2008$. Four of the 10 cities had an improvement in the index, but this was low. The city of Cachoeiras de Macacu improved the most on the ICGRm (62\%), while none of the others reached beyond $21 \%$ improvement, as shown in Table 2 . The cities that presented worsening in the indices were Teresópolis, São José do Vale do Rio Preto, Nova Friburgo, Sumidouro and Petrópolis. The last obtained the second best score, both in 2007-2008 and in 2016, and the observed deterioration was not that significant (16\%). Despite the deterioration in the evaluation index, the city of Petrópolis has shown concern for the continuous improvement of the system, through improvements such as GPS vehicle control and geotechnical and environmental monitoring measures of the landfill. 
Table 1 -Results of the evaluation of waste management in the cities of the state of Rio de Janeiro in 2008 (Dantas et al., 2008)

\begin{tabular}{|c|c|c|c|c|c|c|c|c|c|}
\hline \multirow{3}{*}{$\begin{array}{c}\text { Cities } \\
\text { Nova Friburgo } \\
\end{array}$} & \multirow{3}{*}{$\begin{array}{c}\text { Size Classification } \\
\text { Medium } \\
\end{array}$} & \multicolumn{6}{|c|}{ Worksheet items } & \multirow{3}{*}{$\begin{array}{c}\text { ICGRm } \\
7.69 \\
\end{array}$} & \multirow{3}{*}{$\begin{array}{c}\text { Waste } \\
\text { Condition } \\
\text { Inadequate }\end{array}$} \\
\hline & & \multicolumn{2}{|c|}{$\begin{array}{c}\text { System } \\
\text { features } \\
(32)\end{array}$} & \multicolumn{2}{|c|}{$\begin{array}{c}\text { System planning } \\
\text { (38) }\end{array}$} & \multicolumn{2}{|c|}{$\begin{array}{c}\text { Operating } \\
\text { conditions } \\
(60)\end{array}$} & & \\
\hline & & 29 & 9.03 & 29 & 7.63 & 42 & 7.00 & & \\
\hline Petrópolis & Medium & 26 & 8.12 & 23 & 6.05 & 49 & 8.17 & 7.54 & Inadequate \\
\hline Duas Barras & Small & 25 & 7.81 & 19 & 5.00 & 44 & 7.33 & 6.77 & Inadequate \\
\hline Cantagalo & Small & 24 & 7.50 & 20 & 5.26 & 41 & 6.83 & 6.54 & Inadequate \\
\hline Sumidouro & Small & 22 & 6.87 & 16 & 4.21 & 42 & 7.00 & 6.15 & Inadequate \\
\hline $\begin{array}{c}\text { São José do Vale R. } \\
\text { Preto } \\
\end{array}$ & Small & 22 & 6.87 & 22 & 5.79 & 35 & 5.83 & 6.08 & Inadequate \\
\hline Carmo & Small & 24 & 7.50 & 22 & 5.79 & 29 & 4.83 & 5.77 & Inadequate \\
\hline $\begin{array}{c}\text { Santa Maria } \\
\text { Madalena } \\
\end{array}$ & Small & 24 & 7.50 & 19 & 5.00 & 30 & 5.00 & 5.62 & Inadequate \\
\hline Casimiro de Abreu & Small & 17 & 5.31 & 19 & 5.00 & 36 & 6.00 & 5.54 & Inadequate \\
\hline Teresópolis & Medium & 17 & 5.31 & 22 & 5.79 & 29 & 4.83 & 5.23 & Inadequate \\
\hline Cordeiro & Small & 19 & 5.94 & 19 & 5.00 & 29 & 4.83 & 5.15 & Inadequate \\
\hline Bom Jardim & Small & 23 & 7.19 & 14 & 3.68 & 21 & 3.50 & 4.46 & Inadequate \\
\hline Quissamã & Small & 17 & 5.31 & 15 & 3.95 & 26 & 4.33 & 4.46 & Inadequate \\
\hline $\begin{array}{c}\text { Conceição de } \\
\text { Macabu }\end{array}$ & Small & 15 & 4.68 & 20 & 5.26 & 22 & 3.67 & 4.38 & Inadequate \\
\hline Trajano de Moraes & Small & 14 & 4.37 & 14 & 3.68 & 23 & 3.83 & 3.92 & Inadequate \\
\hline $\begin{array}{l}\text { São Sebastião do } \\
\text { Alto }\end{array}$ & Small & 21 & 6.56 & 11 & 2.89 & 19 & 3.17 & 3.92 & Inadequate \\
\hline Carapebus & Small & 15 & 4.68 & 11 & 2.89 & 21 & 3.50 & 3.62 & Inadequate \\
\hline $\begin{array}{l}\text { Cachoeiras } \\
\text { deMacacu }\end{array}$ & Medium & 13 & 4.06 & 17 & 4.48 & 17 & 2.83 & 3.62 & Inadequate \\
\hline Macuco & Small & 14 & 4.37 & 13 & 3.42 & 19 & 3.17 & 3.54 & Inadequate \\
\hline Silva Jardim & Small & 10 & 3.12 & 11 & 2.89 & 18 & 3.00 & 3.00 & Inadequate \\
\hline
\end{tabular}

Legend: Classification of cities according to the number of inhabitants:

-Small: up to 30,000 inhabitants;

-Medium: from 30,000 to 250,000 inhabitants;

-Large: over 250,000 inhabitants.

The worsening is due to factors such as the regular aspect of the sites for sweeping, bad appearance of weeding and pruning and for failing to carry out performance control due to budget constraints, in addition to not recycling organic matter.

Table 2 - Results of the evaluation of waste management in the cities of the state of Rio de Janeiro in 2016

\begin{tabular}{c|c|c|c|c|c}
\hline Cities & $\begin{array}{c}\text { ICGRm (2007- } \\
2008)\end{array}$ & $\begin{array}{c}\text { ICGRm } \\
(2016)\end{array}$ & Comparison & $\begin{array}{c}\text { Percentage of ICGR } \\
\text { evolution (\%) }\end{array}$ & Result \\
\hline Bom Jardim & 4.46 & 4.62 & Improvement & 4 & Inadequate Management \\
\hline $\begin{array}{c}\text { Cachoeiras de } \\
\text { Macacu }\end{array}$ & 3.62 & 5.85 & Improvement & 62 & Inadequate Management \\
\hline Cantagalo & 6.54 & 7.08 & Improvement & 8 & Inadequate Management \\
\hline Silva Jardim & 3 & 3.62 & Improvement & 21 & Inadequate Management \\
\hline Petrópolis & 7.54 & 6.31 & Deterioration & -16 & Inadequate Management \\
\hline $\begin{array}{c}\text { São José do V. } \\
\text { do Rio Preto }\end{array}$ & 6.08 & 3.23 & Deterioration & -47 & Inadequate Management \\
\hline Teresópolis & 5.23 & 3.62 & Deterioration & -31 & Inadequate Management \\
\hline Nova Friburgo & 7.69 & 7.08 & Deterioration & -8 & Inadequate Management \\
\hline Sumidouro & 6.15 & 4.38 & Deterioration & -29 & Inadequate Management \\
\hline $\begin{array}{c}\text { Casimiro de } \\
\text { Abreu }\end{array}$ & 5.54 & 2.92 & Deterioration & -47 & Inadequate Management \\
\hline
\end{tabular}




\section{Conclusions}

The present study compared the situation of waste management in 10 cities in the state of Rio de Janeiro in 2007-2008 with the current situation. Unfortunately, we found that although six years had passed since the establishment of the National Solid Waste Policy (PNRS), little improvement was observed, and in most cities the situation was actually worse. The only verified effect of this policy was the relative reduction of the irregular disposal of waste in cities, at least indiscriminately. Out of the 10 cities studied in 2016, six of them did not present adequate waste disposal in 2008. They are Cachoeiras de Macacu, Sumidouro, Cantagalo, Teresópolis, Silva Jardim and São José Do Vale do Rio Preto. In the survey conducted in 2016, we verified that only one of them sent waste to an open dump (Teresópolis). Despite previously having disposed of residues in a supposedly controlled manner, due to political, legal and administrative problems the city administration now disposes of wastes without any control. Even in the cities that closed their dumps, it was not uncommon to find occurrences of irregular waste disposal. Another finding is that the regional arrangements and consortiums for the regional disposal of waste in the state of Rio de Janeiro are not working: in some cities where the research was conducted, the waste is disposed in remote landfills, including disposal in another state, increasing the expense for transportation, despite the possibility of forming consortiums with neighboring cities that have landfills, reducing the costs. This general failure of the laudable idea of neighboring cities joining together to rationalize disposal of solid waste and achieve economies of scale is at least partly due to political patronage issues.

We also verified the great difficulty of all the cities surveyed in improving the ways of charging for services, since only the city of Petrópolis, in 2008, was financially self-sufficient in waste management. In 2016, this economic sustainability was no longer present, because of problems in the management of collection between the municipal government and the independent public company responsible for waste management. Another finding was that two of the ten cities studied do not charge any fees related to public cleaning services, being totally dependent on government budget allocations. Also, actions aimed at environmental education focused on the correct separation of solid waste by residents into recyclable, non-recyclable and organic waste and minimization of waste generation are incipient or absent.

Only the city of Sumidouro made composting of biodegradable organic waste in 2008, whose plant was private and not linked to the city. In 2016, this activity was no longer carried out in that city. In addition, there were no adequate and feasible techniques for sorting, recycling and treating waste. While developed countries in 2008 had already greatly reduced the shipment of waste to landfills, 18 of the 20 cities studied still sent waste to dumps or allegedly (but not actually) controlled landfills. In 2016, only the city of Cantagalo performed composting of the biodegradable organic matter, but the separation at the source and operation of the system needs improvements. Most of the analyzed cities outsource part of the activities of the waste management system, thus requiring control and regulation, items still incipient and flawed. Often the contracts are carried out by different government bodies without a standardization of the collection and regulation forms.

\section{Acknowledgment}

This study did not receive any specific grant from funding agencies in the public, commercial, or not-for-profit sectors. We thank the National Research Council (CNPq), Rio de Janeiro State Research Foundation (FAPERJ) and Office to Improve University Personnel (CAPES) and the German Academic Exchange Service (DAAD).

\section{References}

CETESB/SEMA. Inventário Estadual de Resíduos Sólidos Domiciliares - Relatório de 2001, São Paulo, SP, Companhia de Tecnologia de Saneamento Ambiental, Secretaria de Estado de Meio Ambiente, Estado de São Paulo, 2002.

CETESB/SEMA, 2016, Inventário Estadual de Resíduos Sólidos Domiciliares - Relatório de 2015, São Paulo, SP. Companhia de Tecnologia de Saneamento Ambiental, Secretaria de Estado de Meio Ambiente, Estado de São Paulo, 2016.

CONAMA nº 307. "Resolução que estabelece diretrizes para o gerenciamento de resíduos da construção civi", Conselho Nacional do Meio Ambiente, Brasília, Brasil, 2002.

CONAMA nº 358. "Resolução que dispõe sobre o tratamento e a disposição final de resíduos sólidos do serviço de saúde", Conselho Nacional do Meio Ambiente, Brasília, Brasil, 2005. 
CSILLAG, João Mario . A Análise do Valor e A Teoria das Restrições. In: João Mário Csillag. (Org.). Análise do Valor. Análise do Valor. 4ed.São Paulo: Atlas, 1995, v. 1

DANTAS, K. M. C.; MAHLER, C. F.; MENDEZ, G. P.; AZEVEDO, J. P. S.; Avaliação dos Sistemas de Gestão Integrada de Resíduos Sólidos em Municípios. Artigo em avaliação. Engenharia Sanitária e Ambiental - ABES, Rio de Janeiro-RJ, 2016.

DECRETO-LEI FEDERAL n 11.107, “Normas Gerais de contratação de Consórcios Públicos”, Brasil, 06 de abril de 2005.

DEUS, A. B. S., CLARKE, R. T., LUCA, S. J. “Índice de Impacto dos Resíduos Sólidos Urbanos na Saúde Pública (IIRSP): Metodologia e Aplicação”, Engenharia Sanitária e Ambiental, volume 9, n 4, Out./Dez. 2004.

FERNANDES, V. Mais prazo reabre debate sobre lixões. Revista BIO/ABES, Rio de Janeiro, Jul/Set. 2015.

GODOY, M. R. B. Dificuldades para aplicar a Lei da Política Nacional de Resíduos Sólidos no Brasil, Caderno de Geografia, São Paulo, v.23, n.39. 2013.

HAMADA, J. "Política Nacional de Resíduos Sólidos", I SICOM - Simpósio sobre Compostagem - Ciência e Tecnologia, Botucatu, São Paulo,UNESP, Agosto/ 2004.

MARSHALL, R. E.; FARAHBAKHSH K. Systems approaches to integrated solid waste management in developing countries. Waste Management, Canada: Elsevier, v. 33, pag. 988-1003, 2013.

MAVROPOULOS, A. International Report: Uncontrolled Landfill Investigation - A Case Study in Athens. Waste Management and Research, United Kingdom (UK) v. 17, pag. 159-164, 1999.

NBR ISO 14.031. "Gestão ambiental - Avaliação de desempenho ambiental- Diretrizes", Norma Brasileira, ABNT, Brasil, 2004.

\section{Gabriel de Pinna Mendez}

Universidade Federal do Rio de Janeiro, Brasil

Mestre em Engenharia Civil,

Email: gabrielpmendez@gmail.com

Participação do autor: Primeira redação, contribuições para alterações da metodologia de avaliação, pesquisa de campo (estudo de caso), compilação e análise dos dados, discussão e conclusões.

Claudio Fernando Mahler

Universidade Federal do Rio de Janeiro, Brasil

Departamento de Geotecnia da COPPE/UFRJ,

Email: cfmhaler@gmail.com

Participação do autor: Proposta do tema da pesquisa, desenvolvimento e orinetação do trabalho que serviu de base inicial para este estudo, revisão, proposição e adequação da metodologia de avaliação, revisão da bibliografia, verificação e análise dos dados, discussão e conclusões 